\title{
UTILIZATION OF INDIGENOUS KNOWLEDGE IN FOREST CONSERVATION PRACTICES IN IKOM AGRICULTURAL ZONE OF CROSS RIVER STATE, NIGERIA
}

\author{
${ }^{1}$ CAROLINE LINUS ABOH Ph.D, ${ }^{2}$ EREMI, EMMANUEL OHARA Ph.D \\ and ${ }^{3}$ AYA COMFORT FELIX \\ Department of Agricultural Extension And Rural Sociology \\ University of Calabar, \\ Calabar - Nigeria.
}

\begin{abstract}
This study examined the utilization of indigenous knowledge in forest conservation practices in Ikom Agricultural Zone of Cross River State - Nigeria. It focused on the relationship between the socioeconomic characteristics of the respondents and use of indigenous knowledge in forest conservation, indigenous knowledge-based forest conservation practices, the extent of utilization of indigenous knowledge in forest conservation, and the challenges to the effective utilization of indigenous knowledge for forest conservation. The study adopted a survey design, 190 respondents were randomly selected for the study and data were collected with the aid of a validated structured questionnaire. Data obtained were analyzed using frequency, percentages and Ordinary Least Square. The result revealed that the communities used a wide range of indigenous knowledge systems such as the prohibition of tree felling, fire, logging and farming in forest reserves. They also used taboos, sometimes, vigilante groups, close season and preservation of sacred groves to preserve the forest. It was recommended that government should document and integrate local people into forest management, policies, and implementation.
\end{abstract}

Key words: Indigenous knowledge, Forest conservation, Ikom Agricultural Zone.

\section{INTRODUCTION}

In recent years, nature conservation has taken centre stage in the international development debate. Global calls for governments and non-governmental agencies to collaborate in intensifying efforts to protect environment and biodiversity have particularly gained profound momentum in the face of growing climate change and unsustainable human utilization of natural resources. Forest ecosystems are considered to be one of the most biologically diverse environments on earth - consisting of the most microscopic fauna and flora, to the very large species of plants and animals. Protecting and sustainably managing these resources has remained one of the intractable challenges confronting different countries of the world, particularly sub-Saharan Africa. Forest conservation is the process of using the numerous resources in the forest in a sustainable manner, ensuring their continuous availability to the present and future generations.

According to Larinde (2011) forest conservation encompasses the whole practice of ensuring the survival of the forest ecosystems. It involves the management and utilization of forest and forest biodiversities to meet the need of the present generation without compromising, preventing or depriving the future generation from meeting their needs from the same forest resources.

The declining natural resources especially forest resources has become an issue of global concern. Forest ecosystems are continually being threatened and degraded by the increasing pressures created by the expanding human needs and economic activities. These resources plays important social economic, cultural, educational, scientific, medical and development roles in our survival. The World Summit on Sustainable Development held in Johammesburg (2002) recognized the critical role of biodiversity in the overall sustainable development, poverty eradication, climate regulation, and human well-being and livelihood. Forest resources are used for scientific research, serve as source of government revenue and foreign exchange, generate income, 
help to protect the environment by serving as watersheds, enhance soil fertility play important cultural and educational functions, generate raw materials for industries and food for households; among other functions.

However, conserving these forest resources especially in Ikom Agricultural Zone of Cross River State has been a herculean task. In any case, a comprehensive approach is required to sustainably preserve these resources. One of the approaches enunciated is the integration of indigenous knowledge into conservation practices. Indigenous knowledge has been widely defined but in its simplest form, is the unique traditional or local knowledge that has developed and exists around accumulated life experience of a people in a particular geographic location and is linked to and influenced by their understanding of nature.

Indigenous knowledge, otherwise called 'local or traditional/native knowledge, has been seen as important in addressing complex environmental problems. One of the reasons many government - sponsored conservation initiatives have failed is the inability of government to integrate the local people and their rich traditional knowledge into conservation activities. It is on the strength of this that many agencies conventions and debates (such as inter-governmental platform for Biodiversity and Ecosystem services, World Bank, Intergovernmental Panel on Climate Change Arctic Climate Impact Investment; and the Declaration on the Right of the Indigenous People by the United Nations General Assembly etc.) have focused largely on encouraging the application of indigenous knowledge in the management of environmental resources.

Many experts (Roba and Oba, 2012; Savumi, 2008; Oyewole, Dahunsi and Akntola, 2015; Ogboire, 2012 and Mockinson, 2011) converge on the fact that indigenous knowledge is integral to the conservation of forest resources. Unfortunately, the extent to which indigenous knowledge can be utilized to conserve forest particularly in Ikom Agricultural Zone of Cross River State has not been associated. It is against this background that this study was carried out.

Specific objectives of the study

To examine the relationship between the socioeconomic characteristics of the respondents and the utilization of indigenous knowledge in forest conservation.

To ascertain the indigenous knowledge based forest conservation practices in the study area.

To ascertain the extent of utilization of indigenous knowledge in forest conservation practices in the study area.

To examine the challenges to effective utilization of indigenous knowledge in forest conservation.

\section{METHODOLOGY}

This study was carried out in the Ikom Agricultural Zone of Cross River State which comprises six (6) local government areas; namely; Abi, Boki, Etung, Ikom, Obubra and Yakurr. The study adopted a survey research design. The population of the study consisted of all the community increases in the local government areas selected. The study area was selected purposively due to the prevalence of natural forests in the area. Three local government areas (Boki, Etung and Ikom) representing three (3) agricultural extension Blocks were also selected purposively because these Blocks host one of the most diverse natural forests in West Africa. Five (5) communities (cells) were randomly selected from the Blocks used, and from those communities a total of one hundred and ninety (190) respondents were selected for the study.

The instrument used for data collection was a validated structured questionnaire, interviews and focus group discussion. The questionnaire was divided into four main sections based on the specific objectives of the study. The questionnaire was administered by the researchers with the aid of trained local volunteers. Data obtained were analyzed using descriptive statistics such as frequency counts, percentages, mean and ranking as well as inferential statistics specifically the Ordinary Least Square (OLS) model. The regression model was specified as follows:

$$
Y=f\left(x_{1}+x_{2}+x_{3}+x_{4}+x_{5}+x_{6}+x_{n}-\quad \mu_{i}\right)
$$

Where $\mathrm{y}=$ polychotomous Dependent variable (utilization of indigenous knowledge in forest conservation practices) expressed as low medium, high utilization.

$\begin{array}{lll}\mathrm{X}_{1} & = & \text { age (in years) } \\ \mathrm{X}_{2} & = & \text { Level of education (educated =1, not educated =0) } \\ \mathrm{X}_{3} & = & \text { Marital status (married =1, otherwise }=0) \\ \mathrm{X}_{4} & = & \text { Sex (male }=1, \text { female }=0) \\ \mathrm{X}_{5} & = & \text { Income (in naira) } \\ \mathrm{X}_{6} & = & \text { Experience in conservation practices (in years) }\end{array}$


International Journal of Advances in Scientific Research and Engineering (ijasre), Vol 5 (7), July-2019

$\mathrm{X}_{7} \quad=\quad$ Family size (household number)

$\mu \mathrm{i} \quad=\quad$ Error term

\section{RESULTS AND DISCUSSION}

Table 1 Distribution of respondents according to knowledge of indigenous forest conservation practices in the area

\begin{tabular}{llll}
\hline S/N & Variables & Frequency & Percentage \\
\hline 1 & Prohibition of entry into forest & 160 & 84.21 \\
2 & Prohibition of farming activities in the forest & 170 & 89.47 \\
3 & Use of sanctions against those who enter the forest & 83 & 43.68 \\
4 & Replanting of trees after logging & 147 & 77.37 \\
5 & Forest are kept preserved as sacred grooves & 187 & 98.42 \\
6 & Declaration of certain periods as closed seasons & 150 & 78.95 \\
7 & No one is allowed to build a house in the forest & 67 & 35.26 \\
8 & Cutting of trees for whatever reason is a crime & 31 & 16.32 \\
9 & Prohibition of hunting activity in the forest & 79 & 41.58 \\
10 & Women are not allowed to collect firewood from the & 11 & 5.79 \\
& forest & & 3.68 \\
11 & The forest is seen as evil, hence no one enters it & 7 & 68.42 \\
12 & Enforcement of community laws & 130 & 1.05 \\
13 & Use of vigilate groups to protect the forest & 2 & 22.11 \\
14 & Youth are charged with forest protection & 42 & 85.79 \\
15. & Collection preservation of important forest tree species & 163 & 3.16 \\
16 & Construction of wire fences around the forest & 6 & 95.26 \\
17 & Prohibition of use of fire in the forest & 181 & \\
\hline
\end{tabular}

Source: Field survey, (2017) Note: Multiple responses were recorded

Result in Table 1 shows the various indigenous forest conservation practices in the area and respondents' knowledge of such practices. The result revealed that the respondents had knowledge of a wide range of indigenous forest conservation practices. Specifically, table 1 show that 84.21 percent of the respondents had knowledge of prohibitions of entry into forests. Also, 89.47 percent had knowledge of prohibition of farming activities in the forest. Similarly, 77.37 percent had knowledge of replanting of forest trees after logging, 98.42 percent of the respondents had knowledge of keeping/preserving forests as sacred grooves, and 95.26 percent had knowledge of prohibition of use of fire as a means of forest conservation. From the table, 78.95 percent of the respondents had knowledge of declaration of certain periods as closed seasons, 68.42 percent had knowledge of enforcement of community laws, 85.79 percent were knowledgeable on collection/preservation of important tree species, while 95.26 percent had knowledge of prohibition of use of fire in the forest. This agrees with the views of Rim-Rukeh, Irehievwie and Agbozu, (2003) that, traditional natural resource management was in the form of protecting particular ecosystems or habitats such as sacred grooves, sacred rivers or ponds. They added that the practices concerned related to trees, forests, wildlife and marine organisms and that the environmental wisdom and ethics expressed through these beliefs are useful tools in natural resource management. The FAO (2007) also acknowledged that earliest form of legislative protection of forests adopted by local people was restriction placed on collection of specimens of fauna and flora. They noted also this restriction may be full or partial. 
International Journal of Advances in Scientific Research and Engineering (ijasre), Vol 5 (7), July-2019

Table 2 Mean rating of extent of utilization of knowledge of indigenous forest conservation practices

\begin{tabular}{|c|c|c|c|c|c|c|c|}
\hline \multirow[t]{2}{*}{$\bar{S} / \mathrm{N}$} & \multirow[t]{2}{*}{ Variable } & \multicolumn{3}{|l|}{ High } & \multicolumn{3}{|l|}{ Low } \\
\hline & & \multicolumn{2}{|c|}{ Medium } & & \multirow{2}{*}{$\frac{\bar{x}}{37(37)}$} & \multicolumn{2}{|c|}{ Remarks } \\
\hline 1 & Prohibition of entry into forest & 40)160) & $62(186)$ & 51(102) & & 2.55 & $* *$ \\
\hline 2 & $\begin{array}{l}\text { Prohibition of farming activities in } \\
\text { the forest }\end{array}$ & $12(48)$ & $38(114)$ & $40(80)$ & $100(100)$ & 1.9 & $*$ \\
\hline 3 & $\begin{array}{l}\text { Use of sanctions against those who } \\
\text { enter the forest }\end{array}$ & $20(80)$ & 67(201) & $48(96)$ & $55(55)$ & 2.27 & $*$ \\
\hline 4 & Replanting of trees after logging & $117(468)$ & $59(177)$ & $14(28)$ & - & 3.54 & $* *$ \\
\hline 5 & $\begin{array}{l}\text { Forest are kept preserved as sacred } \\
\text { grooves }\end{array}$ & $92(368)$ & $80(240)$ & $10(20)$ & $8(8)$ & 3.35 & $* *$ \\
\hline 6 & $\begin{array}{l}\text { Declaration of certain periods as } \\
\text { closed seasons }\end{array}$ & $63(253)$ & 67(201) & $43(86)$ & $17(17)$ & 2.93 & $* *$ \\
\hline 7 & $\begin{array}{l}\text { No one is allowed to build a house } \\
\text { in the forest }\end{array}$ & 19(76) & $44(132)$ & $54(108)$ & 73(73) & 2.05 & * \\
\hline 8 & $\begin{array}{l}\text { Cutting of trees for whatever reason } \\
\text { is a crime }\end{array}$ & $30(120)$ & $56(168)$ & $4(8)$ & $100(100)$ & 2.08 & $*$ \\
\hline 9 & $\begin{array}{l}\text { Prohibition of hunting activity in the } \\
\text { forest }\end{array}$ & $14(56)$ & $28(56)$ & 47(94) & 101(101) & 1.76 & $*$ \\
\hline 10 & $\begin{array}{l}\text { Women are not allowed to collect } \\
\text { firewood from the forest }\end{array}$ & - & $10(30)$ & - & $180(180)$ & 1.11 & $*$ \\
\hline 11 & $\begin{array}{l}\text { The forest is seen as evil, hence no } \\
\text { one enters it }\end{array}$ & $8(32)$ & 13(39) & $5(10)$ & $164(164)$ & 1.29 & $*$ \\
\hline 12 & Enforcement of community laws & $77(308)$ & $69(207)$ & $26(52)$ & $18(18)$ & 4.08 & ** \\
\hline 13 & $\begin{array}{l}\text { Use of vigilate groups to protect the } \\
\text { forest }\end{array}$ & $58(232)$ & $90(270)$ & $26(52)$ & $18(18)$ & 4.08 & $* *$ \\
\hline 14 & $\begin{array}{l}\text { Youth are charged with forest } \\
\text { protection }\end{array}$ & $37(148)$ & $118(454)$ & $40(60)$ & $5(5)$ & 2.98 & $* *$ \\
\hline 15. & $\begin{array}{l}\text { Collection preservation of important } \\
\text { forest tree species }\end{array}$ & $87(348)$ & $94(282)$ & $9(18)$ & - & 3.41 & $* *$ \\
\hline 16 & $\begin{array}{l}\text { Construction of wire fences around } \\
\text { the forest }\end{array}$ & - & $8(24)$ & $30(60)$ & $152(152)$ & 1.24 & $*$ \\
\hline 17 & $\begin{array}{l}\text { Prohibition of use of fire in the } \\
\text { forest }\end{array}$ & $170(682)$ & $12(36)$ & $5(10)$ & $3(3)$ & 3.84 & $* *$ \\
\hline
\end{tabular}

Source: Field survey, (2018),

$2.50 ; * *=$ utilized, $*=$ not utilized; decision rule; any mean $\leq 2.50-$ not utilized, any mean $\geq 2.50-$ utilized

Result in Table 2 shows the extent of utilization of the various indigenous forest conservation practices in the area. The result revealed that 9 out of the 17 practices were more utilized than others as they recorded mean scores above the cut-off mark of 2.50. However, 8 of the 17 practices scored mean values below the 2.50 mark and were therefore considered least utilized by the respondents. In particular, it was found that prohibition of entry into the forest (mean $=2.55)$, replanting of trees $($ mean $=3.54)$, preservation of sacred grooves (mean $=3.35$ ) and enforcement of community laws (mean $=3.06$ ) were most utilized. Others were youth charged with forest protection (mean $=2.98$ ), declaration of certain periods as closed seasons (mean $=2.93$ ), use of vigilante groups to protect the forest (mean $=2.87$ ) were utilized by the respondents. This results support the views of ND-HERO (2006) that the adoption and strict enforcement of customary rules concerning land rights and exploitation of natural resources and the adoption of agricultural practices like shifting cultivation, helping the conservation of forests. It also agrees with Abere and Ezenwaka's (2011) ascertain that forest community people have used their extensive knowledge of the land and natural resources to form ancient habits, rules and practices which they use to regulate their exploration and by so doing conserve them. However, the use of sanction against those who enter the forest $(\overline{\mathrm{X}}=2.27)$ cutting of trees for whatever reason is a crime $(\overline{\mathrm{X}}=2.08)$ and no one is allowed to build a house in the forest $(\bar{x}=2.05)$ were only moderately utilized in the area. The indigenous knowledge forest conservation practices least utilized were prohibition of farming activities in the forest $(\overline{\mathrm{X}}=1.81)$, prohibition of hunting activities $(\overline{\mathrm{x}}=1.75)$ and construction of wire fence around the forest $(\overline{\mathrm{x}}=1.24)$ etc. This result suggests that although a wide range of indigenous forest conservation practices existed in the area, it is not all of the practice that were effectively utilized. 
Also, the high extent of use of most indigenous forest conservations practices in the study area goes to show the relevance of incorporating the ideas and experiences of the forest community people in conservation efforts. This position supports the co-management paradigm, which emphasizes that people living close to the forests have tremendous experience which they have used over time to conserve them. These findings are supported by Blaike (2011), Berkes (2004) and UNDP (2004) who asserted that this ecosystem management approach usually include conservation efforts by and for local communities, so as to conserve biodiversity and reduce poverty.

Table 3. Mean rating of effectiveness of indigenous knowledge utilized for indigenous forest conservation practices in the area

\begin{tabular}{|c|c|c|c|c|c|c|}
\hline \multirow[t]{2}{*}{$\mathrm{s} / \mathrm{n}$} & \multirow[t]{2}{*}{ Variable } & \multicolumn{5}{|c|}{ Effectiveness } \\
\hline & & $\begin{array}{l}\text { Very } \\
\text { effective }\end{array}$ & Effective & Not effective & $\bar{x}$ & Rank \\
\hline 1 & Prohibition of entry into forest & $110(330)$ & $60(120)$ & $20(20)$ & 2.47 & $8^{\text {th }}$ \\
\hline 2 & $\begin{array}{l}\text { Prohibition of farming activities in } \\
\text { the forest }\end{array}$ & $107(321)$ & $48(96)$ & $35(35)$ & 2.38 & $9^{\text {th }}$ \\
\hline 3 & $\begin{array}{l}\text { Use of sanctions against those who } \\
\text { enter the forest }\end{array}$ & $62(186)$ & $119(238)$ & $9(9)$ & 2.28 & $10^{\text {th }}$ \\
\hline 4 & Replanting of trees after logging & $180(540)$ & $10(20)$ & - & 2.95 & $11^{\text {th }}$ \\
\hline 5 & $\begin{array}{l}\text { Forest are kept preserved as sacred } \\
\text { grooves }\end{array}$ & $47(141)$ & $42(84)$ & $20(20)$ & 1.29 & $14.5^{\text {th }}$ \\
\hline 6 & $\begin{array}{l}\text { Declaration of certain periods as } \\
\text { closed seasons }\end{array}$ & $96(288)$ & $89(178)$ & $54(54)$ & 2.74 & $6^{\text {th }}$ \\
\hline 7 & $\begin{array}{l}\text { No one is allowed to build a house } \\
\text { in the forest }\end{array}$ & $186(558)$ & $77(154)$ & $17(17)$ & 3.84 & $1^{\text {st }}$ \\
\hline 8 & $\begin{array}{l}\text { Cutting of trees for whatever reason } \\
\text { is a crime }\end{array}$ & $10(30)$ & - & $4(4)$ & 0.18 & $17^{\text {th }}$ \\
\hline 9 & $\begin{array}{l}\text { Prohibition of hunting activity in the } \\
\text { forest }\end{array}$ & $27(81)$ & $28(56)$ & $152(152)$ & 1.52 & $12^{\text {th }}$ \\
\hline 10 & $\begin{array}{l}\text { Women are not allowed to collect } \\
\text { firewood from the forest }\end{array}$ & - & $90(180)$ & $73(73)$ & 1.33 & $13^{\text {th }}$ \\
\hline 11 & $\begin{array}{l}\text { The forest is seen as evil, hence no } \\
\text { one enters it }\end{array}$ & $139(417)$ & $11(22)$ & $179(179)$ & 3.25 & $3^{\text {rd }}$ \\
\hline 12 & Enforcement of community laws & $170(510)$ & $41(82)$ & $10(10)$ & 3.17 & $4^{\text {th }}$ \\
\hline 13 & $\begin{array}{l}\text { Use of vigilante groups to protect } \\
\text { the forest }\end{array}$ & $54(162)$ & $20(40)$ & - & 1.06 & $16^{\text {th }}$ \\
\hline 14 & $\begin{array}{l}\text { Youth are charged with forest } \\
\text { protection }\end{array}$ & $160(480)$ & $100(200)$ & $36(36)$ & 3.77 & $2^{\text {nd }}$ \\
\hline 15. & $\begin{array}{l}\text { Collection preservation of important } \\
\text { forest tree species }\end{array}$ & $160(480)$ & $26(52)$ & $4(4)$ & 2.82 & $5^{\text {th }}$ \\
\hline 16 & $\begin{array}{l}\text { Construction of wire fences around } \\
\text { the forest }\end{array}$ & $17(51)$ & $21(42)$ & $152(152)$ & 1.29 & $14.5^{\text {th }}$ \\
\hline 17 & $\begin{array}{l}\text { Prohibition of use of fire in the } \\
\text { forest }\end{array}$ & $118(354)$ & $54(108)$ & $18(18)$ & 2.53 & $7^{\text {th }}$ \\
\hline
\end{tabular}

Source: Field survey, (2018), midpoint $=2.00, \mathrm{n}=190$. Note: Multiple responses were recorded

Result in Table 3 shows the effectiveness of indigenous knowledge utilized for utilized knowledge of indigenous forest conservation practices in the area. It was found that 11 out of 17 conservation practices identified were effective and recorded mean scores above the cut-off point of 2.00, which means that the respondents rated the practices as effective. In the order of effectiveness, the results revealed that no one is allowed to build a house in the forest (ranked first), youth are charged with forest protection (ranked second), forest is seen as evil, hence no one enters it (ranked third) and enforcement of community laws (ranked fourth) were considered most effective. Other indigenous knowledge forest conservation practice effectively utilized were collection and preservation of important tree species (ranked fifth), declaration of certain periods as closed seasons (ranked sixth), prohibition of use of fire in the forest (ranked seventh), prohibition of entry into forest (ranked eighth), prohibition of farming activities in the forest (ranked ninth), use of sanctions against those who enter the forest (ranked tenth) and replanting of forest trees (ranked eleventh). 
Indigenous knowledge forest conservation practices such as cutting of trees for whatever reason is a crime (ranked seventeenth), use of vigilante groups to protect the forest (ranked sixteenth), construction of wire fence around the forest among others, were considered not effective by the respondents. These findings corroborates the position of FAO (2007) that through indigenous knowledge the community people collect and preserve seeds and seedlings of important tree species to sustain the natural forests.

The findings also goes to show that the local community people, using indigenous knowledge in forest conservation, have developed the habit of planting important tree species, thereby domesticating most of them for ready economic and other gains. The implication of this is that most of the indigenous forest conservation practices are effective in the study area and so have been used to promote the conservation of forests by the respondents. Above all, the results have shown that indigenous knowledge in forest conversation practice forms part of the life of local community people living around the natural forests. And as was asserted by Larsen and Springer (2016), it has not been in the interest of these people to over-exploit the forests, knowing too well that their livelihoods depend to a very large extent on these natural resources. Thus, it is important to align with the position of Ogar, Ojating and Aya (2013) that there is growing consensus that local people should be incorporated into the conservation, management and development of the world's remaining forests.

Table 4. Distribution of respondents according to challenges of utilizing indigenous knowledge in forest conservation practices in the area

\begin{tabular}{llll}
\hline S/N & Variables & Frequency & Percentage \\
\hline 1 & $\begin{array}{l}\text { Lack of recognition of indigenous knowledge by new } \\
\text { generation }\end{array}$ & 109 & 57.37 \\
2 & $\begin{array}{l}\text { Lack of government support on documentation/protection of } \\
\text { indigenous knowledge practices }\end{array}$ & 170 & 89.57 \\
& & & \\
3 & Illegal poaching & 187 & 98.42 \\
4 & Lack of effective enforcement of community laws & 163 & 85.79 \\
5 & Religious practices & 94 & 49.47 \\
6 & Wild fire & 114 & 60.00 \\
7 & Failure of government to involve community & 159 & 83.68 \\
8 & Illegal fuel wood collection farming activities & 169 & 88.95 \\
9 & Natural disasters like gully erosion, earth tremor, landslides, & 144 & 75.79 \\
& etc. & & 85.26 \\
\hline
\end{tabular}

Source: Field survey, (2018) Note: Multiple responses were recorded

Result in Table 4 reveals that a number of challenges were associated with the utilization of indigenous knowledge for forest conservation practices in the area. The table shows that 57.37 percent of the respondents cited lack of recognition of indigenous knowledge by the new generation as challenge to utilization of indigenous knowledge forest conservation practices. Also, 89.57 percent of the respondents considered lack of government support on documentation and protection of indigenous knowledge practices. From the table, 98.42 percent, pointed at illegal poaching as a major challenge to utilizing indigenous knowledge in forest conservation practices in the area. Similarly, 85.79 percent of the respondents cited lack of effective enforcement of forest laws, 49.47 percent cited religious practices, while 60.00 percent cited wild fire as challenge. Failure of government to involve community people in forest conservation efforts was cited by 88.95 while percent indicated that illegal fuel wood collection and farming activities as challenges.

The reason for the prevalence of these challenges could be attributed to the rising proportion of stranger elements, infiltrating most forest communities, with the sole aim of trading on forest products. Most of these are said to have desperately circumvented the ideals of conservation, doing things that encourage illegal poaching. Peters (2003) in Bisong (2014) asserted that forest communities can act as watch-gods to report all activities that negatively affect the forests such as illegal poaching, felling of trees and fire outbreaks etc, 
International Journal of Advances in Scientific Research and Engineering (ijasre), Vol 5 (7), July-2019

Table 5. Summary of regression analysis of relationship between the socioeconomic characteristics of respondents and the use of knowledge of indigenous forest conservation practices

\begin{tabular}{llllll}
\hline Variable & $\begin{array}{l}\text { Unstandardized } \\
\text { coefficient }\end{array}$ & Std error & $\begin{array}{l}\text { Standard } \\
\text { coefficient }\end{array}$ & t-value & Sig. \\
\hline Constant & 12.205 & 0.205 & & 59.536 & 0.012 \\
Gender (X1) & 0.762 & 0.128 & 0.386 & 5.944 & 0.27 \\
Marital status (X2) & -0.478 & 0.152 & -0.303 & -3.145 & 0.042 \\
Age (X3) & 0.956 & 0.558 & 0.416 & 1.713 & 0.006 \\
Education level (X4) & 0.095 & 0.099 & 0.024 & 0.957 & 0.440 \\
Family size (X5) & 0.605 & 0.127 & 0.325 & 4.764 & 0.028 \\
Occupation (X6) & -0.009 & 0.096 & -0.002 & -0.091 & 0.936 \\
Monthly income (X7) & 1.567 & 0.650 & 0.454 & 2.411 & 0.004 \\
$\mathrm{R}=.970$ & & & & & \\
$\mathrm{R}=.941$ & & & & & \\
Adjusted R ${ }^{1}=.933$ & & & & & \\
Std error of estimate $=51164$ & & & & & \\
\end{tabular}

*Significant at 0.05 level, independent variable use of knowledge of indigenous forest conservation practices

Result in Table 5 shows that the strength of association between the dependent and independent variables by the model $\mathrm{R}$ value coefficient of determination $\left(\mathrm{R}^{2}\right)$ was seen to be 941 which revealed that 94 percent of the variation in the respondents' use of indigenous knowledge forest conservation practices (predictor variable was jointly explained by the seven (7) dependent or explanatory variable $\left(\mathrm{x}_{1}-\mathrm{x}_{7}\right)$.

At .05 level of significance four (4) out of the seven (7) explanatory variables were found to be significant. The weights and the significance were assessed using the standardized coefficient and t-value, the higher the value of the standardized coefficient, the more influence of the predicator variable on the dependent variable. Specifically, the result reveald that gender, marital status, family size and monthly income were significantly related to the respondents use of indigenous knowledge in forest conservation. From the regression analysis, the relationship between gender, family size and monthly income and utilization of knowledge of indigenous forest conservation practices were positively significant showing $(R=5.94, P<0.05),(R=4.764, P<$ $0.05)$, and $(\mathrm{R}=2.411, \mathrm{P}<0.05)$ respectively. The implication of this is that gender, family size and income have direct influence on level of utilization of indigenous knowledge forest conservation practices. Specifically, the result shows that an increase in income level of the respondents, can increase their utilization of knowledge of indigenous forest conservation practices. The relationship between marital status and utilization of knowledge of indigenous forest conservation practice was however, negatively significant with $(\mathrm{R}=3.145, \mathrm{P}<0.05)$. This implies that though marriage is important and has tremendous influence on the life of people, it does not significantly alter their application as utilization of indigenous knowledge in forest practices.

The result show that age, level of education and occupation were not significant, implying that they had no influence on use of indigenous knowledge in forest conservation practices. With a greater number of socio-economic variables being significantly related to respondents' use of indigenous knowledge forest conservation practices, it goes to confirm that utilization of these practices can be influenced by respondents' socioeconomic characteristics in the forest communities.

The null hypothesis (Ho) which says that there is no significant relationship between the socioeconomic characteristics of respondents and the use of indigenous knowledge forest conservation practices was rejected. While the alternate hypothesis (HI) that there is a significant relationship between the socioeconomic characteristics of respondents and the use of indigenous knowledge forest conservation practices was accepted. The result agrees with the findings of Brown (2013) that there exists strong relationship between indigenous knowledge utilization and conservation of forest resources.

\section{CONCLUSION}

The utilization of indigenous knowledge in forest conservation practices is very important and fundamental to the sustainability of forest resources. This study revealed that the local people have developed rich knowledge systems that are used in the protection and sustainable conservation of forest biodiversities. The local people used sacred grooves, prohibition of fire, restriction on indiscriminate entry, hunting, farming and fuel wood collection, collection and preservation of important tree species, planting of forest, use of open and close season, use of local taboos and sanctions as well as constitution of local vigilante groups to protect designated forest and game reserves, etc to conserve forest. It was further discovered that the local people despite facing enormous challenges, have continued to manage the forest resources at their disposal using varied community- 
based approaches. The implication is that, with appropriate government support, intervention and integration of indigenous knowledge into forest conservation and management policies, substantial progress and success could be achieved in nature conservation.

\section{RECOMMENDATIONS}

The following recommendations were made based on the followings of the study.

- Government should encourage the documentation of indigenous knowledge to make it readily available to the present and future generations.

Local communities should be involved in the design and implementation of forest policies.

Community ownership of forest should be encouraged to allow local people to take responsibility for the protection of forest resources.

\section{REFERENCES}

1. Abere, S. A. \& Ezenwaka, J. (2011). Evaluation of forest resources conservation laws in Nigeria. Mediterranean Journal of Social Science. 2(5): 50-63.

2. Berkes, F. (2004). Rethinking community-based conservation. Conservation Biology. 18(3): $621-630$.

3. Bisong, F. E. (2011). Farming systems and biodiversity conservation towards a theory and model for sustainable natural resource management. In Bisong F. E. (eds). Natural resource use and conservation systems for sustainable rural development. Calabar: Baal International Company.

4. Blaike, P. (2011). Development, post, anti and populist: a critical review. Environment and Planning. 32(6): 1033 1050 .

5. Brown, K. (2013). Three challenges for real people-centered conservation. Global Ecology and Biogeography, 12(2): 89 $-96$.

6. Food and Agriculture Organization, (FAO, 2007). State of the World's forests. FAO, Rome. www.fao.org/wfr/factsheetresources. Retrieved $8^{\text {th }}$ September, 2016.

7. Larinde, R. C. (2011). Sustainable forest management. Ibadan: Hilton Press.

8. Larsen, P. B. \& Springer, J. (2016). Mainstreaming WWF principles: Indigenous peoples and conservation in project and programme management. Gland, Switzerland and Washington, D. C.: WWF.

9. Mackinson, S. (2011). Integrating local and scientific knowledge: An example in fisheries science. Environmental Management, 27(4): $542-545$.

10. ND-HERO (2006). Institutional structure, policies and legal framework. In: The Renewable Natural Resources of the Niger Delta, Options for its Sustainable Management edited by Augusine Ezealor and Olumide Akinsola, Macarthur Foundation USA/NCE; $32-42$.

11. Ogar, D. A., Ojating, I. \& Aya, F. A. (2013). Community forestry and forest stakeholders' participation in sustainable forest management. Paper presented at the $39^{\text {th }}$ Annual conference of Forestry Association of Nigeria, FAN. Forest Research Institute of Nigeria, FRIN, Ibadan.

12. Ogboire, L. (2012). Natural pesticides for the taking, CORAF ACTION, Dakar.

13. Oyewole, S. O., Dahunsi, O. M. \& Akintola, A. L. (2015). Socio-economic assessment of farmers' participation in agroforestry system in Ekiti State, Nigeria. Forestry Research Institute of Nigeria, FME, Forest Hill, Jericho, Ibadan. Net Journal of Agricultural Science, 3(4): 99-103.

14. Peters, r. (2003). Conserving agro-biodiversity. ibadan: University Press.

15. Rim-Rukeh, A., Irehievwie, G. \& Agbozu, I. E. (2013). Traditional beliefs and conservation of natural resources. International Journal of Biodiversity and Conservation, 5(7): 426 - 432.

16. United Nations Development Programme (UNDP, 2004). Programme report, Geneva. 